\title{
Fra løsninger til \\ nye spørgsmål. \\ Kandidatspecialet \\ som forskningsfelt
}

Tine Wirenfeldt Jensen, ph.d.-studerende, Center for Undervisningsudvikling, Det Humanistiske

Fakultet, Aarhus Universitet

Søren S. E. Bengtsen, ph.d.-studerende, Institut for Didaktik, Danmarks Padagogiske

Universitetsskole, Aarhus Universitet.

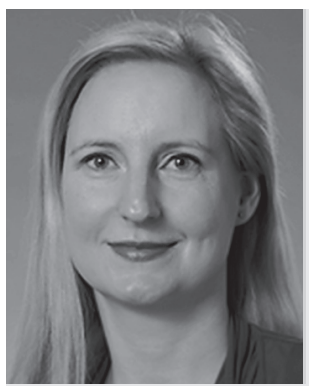

Tine W. Jensen er

ph.d.-studerende og videnskabelig medarbejder ved CFU, Det Humanistiske Fakultet, AU. Hun er uddannet cand.mag. i litteraturhistorie og informationsvidenskab fra $A \cup$ og har i en årrække været ansat ved CFU, hvor hun har arbejdet med undervisningsudvikling og undervisning af studerende, ph.d.-studerende og andre ansatte ved Aarhus Universitet i bl.a. vejledning, den akademiske genre og skriveprocesser.Tines ph.d.-projekt omhandler en undersøgelse af, hvad der konstituerer specialet som eksamensform på universitetet.

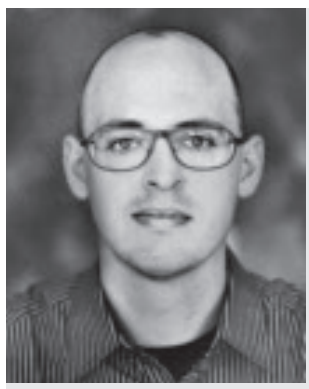

Søren S. E. Bengtsen er ph.d.-studerende ved Institut for Didaktik, DPU, AU, hvor han er ansat under Forskningsprogrammet for de Videregående Uddannelsers Didaktik. Han er uddannet cand. mag. i filosofi og kunsthistorie fra $\mathrm{AU}$ og har flere års erfaring med undervisning og vejledning på bachelor-, master- og kandidatniveau ved AU. Sørens ph.d.-projekt omhandler en undersøgelse af forholdet mellem det personlige og det faglige element i specialevejledningssamtalen på universitetet.

\section{Reviewet artikel}

I denne artikel argumenterer vi for, at der er et behov for flere og varierede metoder og tilgange indenfor universitetspadagogisk forskning $i$ kandidatspecialer. Onsket er at udvide forskningsfeltet, så der kommer et supplement til den overvejende problemorienterede og pragmatiske tilgang, som dominerer på feltet $i$ dag. Vi forsoger at optegne feltets allerede eksisterende tilgange til forskning $i$ kandidatspecialet samt at udpege, hvorledes andre tilgange kan vere givende som supplement til feltet. Vores sigte er at påpege vigtigheden af, at specialet ikke blot ses som noget, man gør, eller noget, man ved noget om, men $i$ høj grad også har at gøre med noget, man er eller bliver til.

\section{Indledning}

Universitetspædagogisk forskning er et relativt nyt forskningsområde i dansk sammenhæng, og meget af det hidtidige arbejde på feltet har været motiveret af presserende, konkrete problemer. Det viser sig ved, at universitetspædagogiske undersøgelser ofte sigter imod at løse problemer og komme med anvisninger til konkrete forbedringer af praksis, f.eks. hvordan man kan øge kvaliteten af specialevejledning, hvordan man håndterer konkrete problemer i vejledningen som eksempelvis forskellige forventninger til forholdet mellem vejledning og bedømmelse eller, hvad den bedste løsning er på udvalgte problemsituationer i vejledningspraksis (Nexø Jensen, 2010, Harboe, 2007, Rienecker et al., 2005). De svar, man kommer frem til, kan være praktisk anvendelige med det samme, og derfor er relevansen af undersøgelser af denne type indlysende. Men hvis sådanne forskningstilgange kommer til at stå alene, 
risikerer vi at miste noget af det, som forskningen $\mathrm{i}$ andre sammenhænge prises for at kunne bidrage med:At undersøge, udfordre og redefinere de grundlæggende forståelser og betydningssammenhænge, der hersker på et givet felt. Risikoen er også stagnation i forskningen. Hvis den universitetspædagogiske forskning skal udvikle sig, så skal den også kunne udpege og rumme problemstillinger, der ikke direkte fremtræder som konkrete problemer, der kalder på en løsning her og nu. Vores udgangspunkt er derfor, at forskningen må stille spørgsmål, der ikke kun giver svar/løsninger på praksisproblemer men også sigter mod at afdække, problematisere og udfolde grundlæggende forståelser og indsigter. Særligt er vores blik rettet mod den herskende universitetspædagogiske forskning om kandidatspecialet som både lærings-, undervisnings- og evalueringsform.

Med denne artikel ønsker vi at pege på nødvendigheden af, at forskningsfeltet åbner sig op imod undersøgelser, der ikke sigter mod at levere løsninger på konkrete problemer, men derimod sigter mod at formulere nye spørgsmål til vores grundlæggende forståelser af og ageren i forhold til kandidatspecialet. For at kunne udføre denne opgave ønsker vi at sætte fokus på nogle af de niveauer, vinkler og nuancer, som en mere instrumentel forståelse af kandidatspecialet ikke kan rumme. Kandidatspecialet er altid allerede en praktisk størrelse - det 'foregår' eller 'finder sted' i bestemte diskursive rum, hvor personer og kontekster er medbestemmende for, hvad der forstås ved kandidatspecialet som praksisfænomen.

\section{Nye vinkler på specialeforskningen: Specialet er også en eksamensform}

Universitetsspecialet er i fokus i disse år og berøres på forskellig vis af nye tiltag og behov: Der lovgives på området, nye behov opstår fra nye fagligheder, og tanken om målopfyldelse blev indført med den nye karakterskala. Der er ligeledes stort fokus på specialets tidsmæssige omfang, på at gøre specialets udformning og indhold direkte relevant for aftagere af kandidater som f.eks. erhvervslivet og på at ruste både vejledere og studerende bedst muligt til at varetage og indgå i specialevejledning. Denne udvikling har sandsynligvis været medvirkende til at skabe et øget forskningsmæssigt fokus på specialet på danske universiteter, hvilket især har vist sig i relation til specialevejledning (se f.eks. Andersen \& Jensen, 2007, Rienecker et al., 2005, Nexø Jensen, 2010, m.fl). Specialevejledning er et i dansk sammenhæng hidtil relativt uudforsket emne, der som megen anden undervisning har eksisteret bag den ofte omtalte lukkede dør, hvorfor forskning på feltet har været og fortsat er nødvendig. Specialevejledning er ikke et isoleret fænomen - det er vejledning hen imod noget, og vejledning forudsætter dermed en specifik forståelse af specialet som lærings- og bedømmelses- form hos vejlederne. At kravene til en eksamensform har betydning for læreprocessen som helhed og de deraf opnåede kompetencer, er et kendt forhold (Dahler-Larsen \& Krogstrup, 2003 m.fl.)

Disse krav er tilstræbt nedfældet $\mathrm{i}$ de enkelte fags studieordninger, som er blevet revideret i forbindelse med indførelsen af den nye karakterskala. Ud over disse korte beskrivelser findes der ganske lidt nedskrevet om specialet af mere formel karakter. ${ }^{1}$ Forståelsen af specialet som eksamensform, dens indhold, formål og særkende, er dermed primært forankret i de faglige miljøer og hos den enkelte specialevejleder. Disse grundlæggende forståelser må antages at have implikationer for, hvordan vejlederne forstår og udfører deres vejlednings- og bedømmelsesopgaver i forhold til specialet, ligesom disse forståelser muligvis også har koblinger til forestillinger om faglig og akademisk identitet. Derfor er det nødvendigt at fokusere på eksamensforms-perspektivet som et grundlæggende konstituerende element i forhold til specialet.

Med Andersens og Tofteskovs Eksamensformer (2008) er der sat fokus på titlens emne i dansk universitetspædagogisk sammenhæng. Der har i de senere år været mange eksperimenter med andre lærings- og bedømmelsesformer end specialet og stor iderigdom i forhold til udvikling af nye eksamensformer som f.eks. portefolio, eksamensformer med fokus på foretagsomhed m.m. (se f.eks. Ambjørn, 2008, Krogh, Lund \& Aarup Jensen, 2008). Men i forhold til specialet har der udover en pragmatisk begrundet reduktion i kravet til omfang overvejende været fokus på undervisningsformen (vejledning) frem for på specialet som eksamensform. På dette område kommer interessen $i$ at afprøve nyt primært til udtryk i eksperimenter med vejledningsformer (f.eks. gruppe- og teamvejledning) eller nye måder at rammesætte f.eks. vejledervalg. Hvor specialevejledningen har været det sidste private rum i relation til undervisningsformer, så fremstår specialet som den sidste eksamensform, der mangler at blive synlig som netop en sådan. Det forekommer stadig overvejende underforstået og traditionsforankret, hvorfor der skrives speciale i en eller anden form på alle fakulteter, hvad vi vil med denne eksamensform i et overordnet perspektiv, begrundelser for dens eksisterende udformninger, og hvad den evt. betyder for universitet som helhed, for fagenes identitet og for de studerendes faglighed. Der er ingen tvivl om, at der er brug for forskning i dette fænomen.

\section{Nye vinkler på specialeforskningen: Diversitet $i$ vejledningen som ressource frem for problem}

Ovenstående pointe, at forskningen inden for specialefeltet oftere har karakter af at være problemløsende end eksplorativ, kan ligeledes overføres til litteraturen om specialevejledning, som må siges at være den del af kandidatspecialet, der har modtaget størst opmærk- 
somhed på den universitetspædagogiske front de sidste tyve år - hvor litteraturen om netop dette emne har været støt voksende både i Skandinavien og internationalt. Især inden for det sidste årti har der været et mere samlet fokus i litteraturen om specialevejledning. Dette fokus har udmøntet sig i ønsket om at påvise den store kompleksitet, der er med til at kendetegne specialevejledningen generelt men også, og måske især, den konkrete specialevejledningssamtale.

Som et (efterhånden klassisk) eksempel på det multidimensionale vejledningsrum har Per Lauvås og Gunnar Handal beskrevet vejledningssituationen som en mangesidig begivenhed, der kan variere på mange planer, og hvor den enkelte vejledningssamtale kan indeholde mange forskellige elementer: (a) krav fra studieordninger, (b) krav til opbygning af specialet som en akademisk tekst, (c) fagdidaktiske traditioner, (d) paradigmatiske og fagtekniske forforståelser, (e) forskellige vejledningstyper (vejleder man f.eks. på specialet som et produkt eller en proces?), (f) samtaleformer (er samtalen en doceren, en debat eller en forhandling?), (g) handlinger der foretages under vejledningssamtalen (giver man feedback, udfører man aktiv lytten, motiverer og inspirerer man, eller er det rådgivning der gives?), samt (h) relationen mellem vejleder og studerende, som ofte kaldes for personlig vejledning og omhandler den personlige 'kemi' mellem vejleder og studerende, der bygger på temaer omkring tillid, anerkendelse og tryghed (Lauvås og Handal, 2006a og 2006b).

Denne eksplicitering af det komplekse vejledningsrum har i litteraturen primært haft det formål at udpege de elementer, der kan give anledning til problemer eller uheldige misforståelser i løbet af specialevejledningsprocessen, samt hvad der så kan gøres for at gribe disse udfordringer i tide, så muligheden for at løse situationen bedst muligt kan optimeres og effektiviseres (Eley \& Jennings, 2005; Eley \& Murray, 2009). Denne udfoldelse af de mange forskellige dimensioner i vejledningsrummet, som kan influere på den enkelte vejledningssituation, har primært handlet om at give guidelines, kommunikationsstrategier samt redskaber til at strukturere specialet som akademisk genre for den studerende og for vejleder selv. Der har været et ønske om at rammesætte specialevejledningen som en akademisk praksis med centrale didaktiske mål samt teknikker til at nå disse mål. Udgangspunktet er således, at kandidatspecialet er et alment universitetspædagogisk fænomen, og at dimensionerne af dette fænomen kan generaliseres på tværs af situationer og faglige sammenhænge.

Et andet centralt fællespunkt $i$ vejledningslitteraturen cirkler om den dobbelthed, der ligger i dels at have ønsket om at kunne udkrystallisere almene redskaber til vejledningspraksis ved universitetet, dels at være bevidst om, at 'slike samtaler kan ikke standardiseres eller gjennomføres etter noen oppskrift' (Lauvås \& Handal, 2006a, p. 101). Gina Wisker pointerer endda, at betyd- ningen af det konkrete vejledningsmøde mellem vejleder og studerende ansigt-til-ansigt ikke kan overvurderes, og at 'supervisory dialogues, whether face-to-face or through electronic/postal/textual means, are the main way in which we work with our students to encourage, direct, support and to empower them to get on with and complete their research and writing' (Wisker, 2005 , p.120). Wisker er optaget af at accentuere diversiteten af tilgange til den konkrete vejledningspraksis, og hun stræber efter at kategorisere og professionalisere forskellige kommunikationsstrategier og samtaleteknikker (Wisker et. al., 2008, p. 86ff). Samme ambition findes hos Wiskers skandinaviske kollegaer Lauvås og Handal (Lauvås \& Handal, 2006b, p.225ff) og herhjemme hos Rienecker, Harboe og Jørgensen (Rienecker, Harboe, Jørgensen, 2005).

Wisker understreger, at 'you will need to identify your own voice and expressions when deciding how and when to interact in which [communicational] categories' [11 kategorier følger] (Wisker, 2005, p.127; se også Wisker et. al., 2003, p.391). Hos Wisker, som hos hendes skandinaviske kollegaer, er ønsket om at udpege den store grad af diversitet efterfulgt af forsøg på at bidrage med løsningen på, hvordan man navigerer $\mathrm{i}$, håndterer og faciliterer læringsprocesser $\mathrm{i}$ forhold til denne diversitet. På denne måde forudsætter (eller skaber?) nuværende tilgange til specialevejledning en i overvejende grad pragmatisk, skematisk og problemløsende mentalitet, der først og fremmest orienterer sig mod at effektivisere og professionalisere specialevejledning på et alment plan.

Som supplement til den anvendelsesorienterede tilgang til forskning i kandidatspecialet argumenterer vi for et øget behov for at nuancere og genopdage denne diversitet, som litteraturen på feltet har ekspliciteret. I stedet for at forstå diversiteten primært som et rum for potentielle pædagogiske konfliktsituationer, der skal findes løsninger på, er det væsentligt at undersøge, om denne diversitet kan være en ressource i arbejdet med specialet som eksamensform og vejledningspraksis. Kandidatspecialet, både set som eksamensform og vejledningspraksis, er et universitetspædagogisk fænomen, der efter vores mening kalder på en gentænkning af dette spændingsfelt mellem pragmatiske og eksplorative tilgange.

\section{Hvilke metaforer uddanner vi med? Den sproglige konstruktion af specialedomænet}

En sådan gentænkning bør inddrage, hvordan vi sprogligt begrebsliggør og strukturerer specialet. At sproget ikke blot er en betegnende men også en aktivt medskabende faktor af vores praksisser, har der tidligere været sat fokus på i dansk universitetspædagogisk sammenhæng, f.eks. i forbindelse med metaforiseringen af vejlederrollen (se f.eks. Andersen og Jensen, 2007). Men det er også værd at opholde sig ved selve betegnelsen 
speciale - et udtryk der er interessant, i og med det bruges til at betegne mange forskellige enkeltdele og overbegreber på en gang: Betegnelsen speciale bruges både om lærings- og eksamensformen som helhed, som underforstået synonym for specialevejledning og diverse policypapers samt som betegnelse for det endelige produkt: Specialeafhandlingen. Men disse elementer er ikke synonymer for hinanden, selvom de ofte anvendes sådan. Hvad der refereres til som specialet, er individuelle, afgrænsede elementer, som tilsammen konstituerer specialet som lærings- og bedømmelsesform. Denne flydende, elastiske og synekdokiske brug af betegnelsen giver nogle særlige udfordringer i forhold til at gøre emnet til genstand for forskning. For når vi undersøger, taler og skriver om specialet, hvad mener vi så? Den færdige tekst, der afleveres? Den overordnede lærings-og bedømmelsesform? Eller henviser betegnelsen derimod til en vejledningsproces, den studerende og vejlederen samarbejder om? I forhold til videnskabelige undersøgelser af specialet rejser de sproglige og betydningsmæssige forskydninger på området en række udfordringer, der kræver en række metodiske overvejelser og greb at arbejde med både i kvantitative og kvalitative undersøgelser. I både interview- og spørgeskemaundersøgelser af specialet bliver det nødvendigt at præcisere, hvilken betydning af specialet der spørges til, ligesom det kan være nødvendigt f.eks. $i$ interviews at bede interviewpersonen uddybe sin egen brug af begrebet.

Men denne flydende brug af terminologi er ikke blot en potentiel forskningsmæssig udfordring. Den udsiger også noget om, hvordan vi konceptualiserer feltet og er med til at udpege specialet som en særlig eksamensform i forhold til andre eksamensformer. Et speciale er sprogligt noget, man kan have, noget man kan aflevere, noget man kan skrive, og noget man på en gang kan uddanne sig med og til. Det er både vejen og resultatet samlet i et enkelt ord. Specialet er dermed ikke blot en lærings- og bedømmelsesform som alle andre på videregående uddannelser men trækker flere betydninger med sig. Specialet synes hermed at indtage en særrolle $i$ forhold til andre eksamensformer og at indtage en privilegeret position i konstruktionen af en faglig identitet. Det er muligvis derfor, at specialeområdet synes at være mere metaforiseret end andre lærings- og bedømmelseformer (se f.eks. Andersen og Jensen, 2007).

Retoriske figurer som synekdoken og metaforen har aldrig kun en ornamental uskyldig funktion. Synekdoken betegner del for helhed (speciale(afhandling) for specialet som eksamensform) eller helhed for del (speciale(eksamensform) for specialevejledning) og konstruerer og viser på én gang iboende relationer mellem elementer på et givent område. Metaforer er aktive; de kan generere og producere hele domæneforståelser (Schön,1993, Lakoff \& Johnson, 1980), som făr reel betydning for, hvordan vi konceptualiserer et felt, herunder afgrænser, italesætter og agerer i det. Med dette perspektiv er det interessant at undersøge, hvilken betydning vores sproglige konstruktion af, hvad man kan kalde et "specialedomæne" (Schön, 1993), har for, hvordan vi uddanner kandidatstuderende gennem specialet. Med Lakoff og Johnson kan man stille spørgsmålet: Hvilke metaforer uddanner vi med på danske universiteter? Og hvilken betydning har denne brug for, hvordan vi forstår, bruger og potentielt udvikler specialet som eksamensform?

\section{Den ontologiske vending inden for universitetspædagogikken}

Herhjemme har lektor ved DPU Finn Thorbjørn Hansen påpeget, at forståelse af en eksamensform og den tilhørende vejledningspraksis ikke kun er noget, man ved og gør; det er i høj grad også noget, man er. På denne måde erklærer Hansen sig enig i Lauvås og Handals og Wiskers pointer om, at den konkrete praksis har en central betydning i vejledningssammenhænge. Hansen distancerer sig dog fra førstnævntes tilgang, som han ser som en reduktion af den konkrete vejledningspraksis til en teknologisering af og pragmatisk tilgang til et fænomen, der også rummer en vigtig, og ofte overset, værensmæssig dimension (Hansen, 2008, p.311-312; Hansen, 2010, p.4). I Storbritannien er denne såkaldte 'ontologiske vending' i universitetspædagogikken promoveret af uddannelsesforskere som Ronald Barnett (Institute of Education, University of London) og Denise Batchelor (Institute of Education, University of London)) (Barnett, 2010; Barnett, 2007; Barnet \& Coate, 2006; Batchelor, 2006; Batchelor, 2008). Ontologi betyder i denne sammenhæng, at der sættes fokus på forholdet mellem det, man er, og det, man gør. Der er på denne måde en relation mellem eksistentielle temaer hos vejledere og studerende og den akademiske praksis, som disse personer handler i og udfra. For Barnett og Batchelor er denne personlige dimension af vejledning og undervisning af største betydning, idet den åbner op for en forståelse af, hvad diversitet er, både i forhold til den akademiske selvforståelse og i forhold til forskellige nuancer og modaliteter ved den faglige samtale:

"Here, the student is coming into herself; is realising herself and inserting herself into her [educational] offerings. Her utterances, her activities, her exchanges are manifestations of her voice. (...) [this voice] contains the hope that the voice will be an authentic voice; the student is pressed for her stories, her reasoning." (Barnett, 2007, p. 93-95)

Ved at fokusere på den ontologiske dimension af universitetspædagogikken får Hansen, Barnett og Batchelor sat den konkrete praksis og selvforståelse i centrum og får således givet en ny dimension til forståelsen af diversitet og differentiering af læring i forhold til kandidatspecialet. Man kan sige, at hvor universitets- 
pædagogikken hos Lauvås og Handal og Wisker primært sætter fokus på almene og generelle pædagogiske greb og teknikker, sætter universitetspædagogikken hos 'ontologerne' primært fokus på den personlige og eksistentielle dimension og fremhæver således, at der er dele af den konkrete undervisningspraksis, der ikke kan generaliseres men må opdyrkes og opdages konkret ved hvert møde. Herved skaber ontologerne en polemisk kløft mellem deres egen og den traditionelle universitetspædagogik, hvor de ser deres egen tilgang som den primære, idet 'the student's ontological and epistemological voices are intertwined, but also the ontological voice has the upper hand. (...) Ontology still trumps epistemology' (Barnett, 2007, p.97. Se også Batchelor, 2008, p. 45-46; Hansen, 2008, p.357-358).

Det vi først og fremmest mener, man bør tage med fra den ontologiske vending i universitetspædagogikken er, at den formår at skabe en diskurs, der kan rumme og synliggøre sprogliggørelsens betydning samt dynamiske, spontane og konkrete praksiselementer af fænomener som f.eks. eksamensformer og specialer.

\section{Konklusion}

Vi har i artiklen argumenteret for, at den universitetspædagogiske forskning bør åbne sig mod at kunne rumme problemstillinger, der ikke i deres udgangspunkt har et pragmatisk, problemløsende sigte.Vi har peget på, hvordan det danske universitetspædagogiske forskningsfelt i høj grad er formet af, at man som aktører på området selv er tæt på de problematikker, der er på feltet, og selv konkret mærker effekten af feltets videnshuller i det daglige arbejde. Vi har forsøgt at vise, hvad nye perspektiver kan bidrage med, og hvordan disse kan være med til at udvide forskningsfeltet i forhold til at få viden om specialet som lærings-, bedømmelses- og praksisform.

Vi har påpeget nødvendigheden af at rette fornyet fokus på det felt af sproglige betydninger, der konstituerer specialet som eksamensform og vejledningspraksis. I forlængelse af denne analyse har vi argumenteret for vigtigheden af nærmere undersøgelser af diversitet som træk i forhold til kandidatspecialet og betydningen heraf.Vi har gjort opmærksom på, at betydningen af kandidatspecialet som et universitetspædagogisk fænomen både skabes igennem institutionelle normer og velforankrede normer for undervisningspraksis, men at specialet også samtidig skabes gennem de enkelte vejlederes faglige og akademiske selvforståelse, som den kommer til udtryk bl.a. i den konkrete vejledningssituation. Derfor er det vigtigt, at fremtidig forskning i kandidatspecialet undersøger dette spændingsfelt mellem norm, praksis, og selvforståelse, og at også den forskning prioriteres, som undersøger de sider af universitetspædagogikken, der ikke i udgangspunktet har til formål at levere løsninger eller nye værktøjer, men hvis primære formål er at nuancere og åbne op for nye mulige forståelser af kandidatspecialet som et universitetspædagogisk fænomen.

\section{Referencer}

Andersen, H. L. \& T. W. Jensen (2007). Specialevejledning - rammer og roller. En universitetspadagogisk undersøgelse. Frederiksberg: Samfundslitteratur.

Andersen, H. L \& J. Tofteskov (2008). Eksamen og eksamensformer betydning og bedommelse. Frederiksberg: Samfundslitteratur.

Ambjørn, L. (2008). Fra mundtlig gruppeeksamen til løbende evaluering med portefolio I: DUT, Dansk Universitetspaedagogisk Tidsskrift. vol. 3, nr. 5, s. 16-21.

Barnett, R. (2010). Being a University. London \& New York: Routledge.

Barnett, R. (2007). A Will to Learn. Being a Student in an Age of Uncertainty. Berkshire: McGraw-Hill.

Barnett, R. \& Coate, K. (2006). Engaging the Curriculum in Higher Education. Berkshire: McGraw-Hill.

Batchelor, D. (2008). Have Students Got a Voice (p.40-54), I: Barnett, R. \& B. Di Napoli (ed.):

Changing Identities in Higher Education. Voicing Perspectives. London and New York: Routledge.

Batchelor, D. (2006). 'Vulnerable Voices: An Examination of the Concept of Vulnerability in Relation to Student Voice' (p.787-800), I:Educational Philosophy and Theory, Vol. 38, No. 6.

Dahler-Larsen, P. \& H. K. Krogstrup (2003). Evalueringers konstitutive virkninger. I: Dahler-Larsen, Peter \& Hanne Kathrine Krogstrup (red.). Tendenser i evaluering. Syddansk Universitetsforlag.

Eley, A. \& R. Jennings (2005). Effective Postgraduate Supervision: Improving the Student/Supervisor Relationship. Open University Press, Berkshire: McGraw-Hill.

Eley, A. \& R. Murray (2009). How to be an Effective Supervisor: Best Practise in Research Student Supervision. Open University Press, Berkshire: McGraw-Hill.

Hansen, F.T. (2008). At stå $i$ det åbne. Dannelse gennem filosofisk undren og norvar. København: Hans Reitzel.

Hansen, F.T. (2010 under udgivelse). "The Phenomenology of Wonder in Higher Education«, I: Malte Brinkmann (ed.). Erziehung. Phänomenologische Perspektiven. Königshausen \& Neumann: Würzburg.

Harboe, T. (2007). "Godkendelsesfælder i BA-projektet og specialevejledning« I: DUT, Dansk Universitetspaedagogisk Tidsskrift. vol. 2 , nr. 3, s. 49-53.

Jensen, Hanne Nexø. (2010), » «Det lukkede rum« - en dør på klem til specialevejledningen«. I: DUT, Dansk Universitetspaedagogisk Tidsskrift. vol. 5, nr.8, s.17-22.

Jørgensen, M. W. \& L. Philips (1999). Diskursanalyse som teori og metode. Samfundslitteratur, Roskilde Universitetsforlag.

Krogh, L., B. Lund og A. Aarup Jensen; »Portfolioevaluering og nye eksamensformer I: Lund, B. (red.). Portfolio $i$ et larings- og uddannelsesperspektiv, Aalborg: Aalborg Universitetsforlag.

Lakoff, George \& Mark Johnson. (1980) Metaphors We Live By. Chicago: University of Chicago Press.

Lauvås, P. \& G. Handal (2006a). Forskningsveilederen. Oslo: Cappelen Akademisk Forlag

Lauvås, P. \& G. Handal (2006b). Vejledning og praksisteori. Århus: Klim.

Rienecker, L., T. Harboe \& P. S. Jørgensen (2005). Vejledning - en brugsbog for opgave- og specialevejledere på videregående uddannelser. Frederiksberg: Samfundslitteratur.

Schön, D.(1993). "Generative Metaphor:A Perspective on Problemsetting in Social Policy«, I: Ortony, Andrew (ed.) Metaphor and Thought. Cambridge University Press.

Wisker, G., G. Robinson, V. Trafford, Warnes, \& E. Creighton, (2003). From Supervisory Dialogues to Successful PhDs: Strategies, Supporting and Enabling the Learning Conversations of Staff and Students at Postgraduate Level, I: Teaching in Higher Education, 8: 3, 383-397. 
Wisker, G. (2005). The Good Supervisor. Supervising Postgraduate and Undergraduate Research for Doctoral Theses and Dissertations, New York: PalgraveMacmillan.

Wisker, G., K. Exley, M. Antoniou \& P. Ridley (2008). Working one-to-one- with Students. Supervising, Coaching, Mentoring and Personal Tutoring. New York: Routledge.

\section{Noter}

1 På en del fag findes en pjece udarbejdet af f.eks. en fagvejleder eller en studievejleder, og det varierer, hvilken udbredelse og status disse dokumenter har. 